\title{
Seasonal Incidence of European Foul Brood and Sac Brood Disease in Apis mellifera L. and their Correlation with Colony and Weather Parameters
}

\author{
Naveen and Ashok Singh Yadav* \\ Department of Entomology, RVSKVV-College of Agriculture, Gwalior (M.P.) India \\ *Corresponding author
}

\section{A B S T R A C T}

\section{Keywords}

Apis mellifera,

Brood disease,

Seasonal incidence,

Colony record,

Weather parameters

Article Info

Accepted:

04 December 2020

Available Online:

10 January 2021
During present studies colony record of Apis mellifera under stationary condition was recorded minimum (3.30 bee frames/conoly) in First fortnight of November 2019 and maximum ( 8.30 bee frames/ colony) in second fortnight of January 2020. Brood area was significantly low (1160.34 $\mathrm{cm}^{2} /$ colony) in second fortnight of October 2019 and high (4013.67 $\mathrm{cm}^{2} /$ colony) in first fortnight of January 2020. Pollen area was minimum (345.0 $\mathrm{cm}^{2} /$ colony) in first fortnight of November 2019 and maximum $\left(1720.71 \mathrm{~cm}^{2} /\right.$ colony) in first fortnight of February 2020. The honey store was observed maximum (1660.50gm/colony) in second fortnight of January 2020. No incidence of EFB disease in Apis mellifera was observed from first fortnight of August to first fortnight of September 2019 and first fortnight of November 2019 to first fortnight of February 2020. The incidence of EFB was found Maximum at 16.0 percent during study period in the first fortnight of October 2019. Incidence of EFB was significantly negative association with colony strength $(r=-0.522)$ and brood area $(r=-0.627)$. The incidence of European foulbrood was found positively correlated with temperature $(\mathrm{r}=0.341)$, and negatively correlated with rainfall $(\mathrm{r}=-0.144)$ and relative humidity $(\mathrm{r}=-0.494)$. Sac brood incidence was reported minimum (2.0\%) in second fortnight of July 2019 and maximum $(7.30 \%)$ in second fortnight of February 2020. No incidence of sac brood was found from first fortnight of August 2019 to second fortnight of January 2020. The incidence of Sac brood disease was found significantly negative correlated with brood area $(r=-0.560)$ and relative humidity being non-significant. Also the incidence of Sac brood disease shows positively correlated with colony strength, average temperature and rainfall, though non-significant.

\section{Introduction}

Honey bees are one among the foremost fascinating and beneficial creatures within the kingdom Animalia. They are the holometabolous insects demonstrating eusociality, showing high degree of social organization and well developed communication and defensive mechanisms.
Bee colony being a source of learning the spirit of social science, equidivision of labour, sense of unity, sacrifice and well recognized as a medium of scientific study. Beekeeping in India dates back to pre-historic era when indigenous methods far from scientific approach were in practice. The winged creature honey bees, find mention in almost all the religious epics, viz., the Vedas, the 
Ramayana, the Quoran and many other ancient books.

The rearing of honeybees, called apiculture, has occupied an important economic status and contributes substantially to the national income, yet, in many parts of the country, particularly in tribal belts, traditional methods of beekeeping till today are in prevalence. Beekeeping is becoming popular due its demand in national and international markets as well. It has been well established that in addition to the source of many valuable products like Pollen, Honey, Royal jelly, Beeswax, Propolis, and Bee venom, honeybees play a pivotal role in the pollination of a wide variety of crops and help in maintaining biological diversity (Johannesmeier and Mostert, 2001). After successive losses in the traditionally grown out crops, farmers are attracting towards bee farming. In order to maximize agricultural production, honeybee is often used as a crucial input agent. About 80 cash crop plants are cross-pollinated, as they have to receive pollen from other plants of identical species with the assistance of external agents. One of the foremost important external agents is that the honeybee.

The cropping system of the Chambal region provides abundant flora for honey bees therefore, this zone of Madhya Pradesh is a paradise for beekeepers not only for the state but also for neighboring states such as Rajasthan and Uttar Pradesh, thus has an enormous potential for profitable beekeeping. It has tremendous back up of bee flora from field crops also as from horticultural crops.

These includes sesame, green gram, black gram, pearl millet, medium duration pigeon pea and Celery (Ajwain) during July to October, Coriander, rape seed and mustard during November to February and Berseem during mid-March to mid-May. During the rest of the year, the flora of forest plants such as Adusa (Adhatoda vasica), Kher (Acacia catechu), Drum-stick (Moringa oleifera), Shisham (Dalbergia sissoo), and Neem (Azadirachta indica) are available in abundance. Therefore, commercial bee keeping is very popular in this area from October to April.

At present four predominant honeybee species viz., Rock bee (A. dorsata F.), Little honey bee (Apis florea F.), Indian honey bee (Apis cerana indica F.) and European honey bee (Apis mellifera L.) are found in India. Amongst the four species, the former two are wild honey bees and have not been domesticated so far anywhere, whereas, the latter two species are domesticated and managed in wooden boxes called hives.

Honey bees are susceptible to a variety of diseases and environmental threats. While it is impossible to identify a single factor which on its own can account for all colony losses in all regions of the world over a given time period, it is clear that several biological and environmental factors acting alone or in combination have the potential to cause premature colony mortality by adversely affecting colony health and lifespan. Among these factors, certain honey bee diseases and parasites have been shown to play a significant role in increased honey bee colony mortality and colony losses (Genersch, 2010).

Presently beekeeping industry is facing many challenges throughout the world. Among these, a major constraint in beekeeping developmental programs is the depredation of a large number of diseases and enemies. Honey bees are attacked by many diseases and insect pests, which cause weakness of colonies and ultimately low honey production. One of the bacterial origin brood disease is European foulbrood caused by Melissocccus plutonius affects mainly 
unsealed brood and younger bee larvae usually when they are four to five days old. The infected larva moves in the brood cell in coiled position and dies somewhat displaced in its cell; twisted around the walls. The colour of the larvae changes as it decays from pearly white to yellow, then brown and finally, when they decompose, greyish black (Bailey, 1961). European foulbrood is very common all over the world, where Apis mellifera L. exists (White, 1912). In India, this disease was recorded for the first time in A. cerana from Maharashtra during 1970 (Diwan et al., 1971).

Sacbrood disease, caused by Morator aetotulas, is perhaps the most common viral disease of honey bees. Sacbrood is a condition affecting the brood of the honeybee, resulting in larval death. Larvae fail to pupate after four days; remained stretched out on their backs in cells. The anterior section of the larva, firstly undergoes colour changes, changing from pearly white to pale yellow and shortly after death they dry out, forming a dark brown gondola-shaped scale (Baily, 1975). Sacbrood occurs most frequently in spring, when the colony is growing most rapidly and large numbers of susceptible larvae and young adults are available (Baily, 1969). Since its first discovery is in Thailand in 1981, it has been found in association with A. cerana in India, Pakistan, Nepal, and other Asian countries. For the first time in India, 2.52 to 2.92 per cent mortality of brood was recorded in A. mellifera colonies during 1998 (Chandel et al., 1999). Incidence of sacbrood disease in A. mellifera was generally noticed during spring and early summer by different research workers at different places of the world (Chandel et al., 1999; Hornitzky and Anderson, 2003).

Diseases, insect pests and other enemies causes moderate to severe damage to honey bee colonies and the same constraints are faced by beekeepers of the region which impairs the health and normal working of honey bees. So, it is of prime importance that beekeepers should be aware of these potential damaging factors and can well protect their honey bee colonies to get the maximum benefit from beekeeping venture. The beekeeping with European honey bee, $A$. mellifera is practiced in the region both under stationary and migratory conditions.

Despite the fact, only few attempts have been made to observe the seasonal incidence of enemies infesting A. mellifera L. So, there was a need for qualitative study and survey of insect pests, pathogens, predators and other enemies of A. mellifera $\mathrm{L}$. with the changing scenario of environmental conditions, which may immensely be helpful for beekeepers to take care of their honeybee colonies.

Thus, keeping all these views in mind, the present study was aimed to provide comprehensive research information on the occurrence of brood diseases of honey bees and the study was conducted.

\section{Materials and Methods}

The present investigations were carried out in the apiary of Apis mellifera L. at RVSKVVKrishi Vigyan Kendra, Morena, Madhya Pradesh, during 2019-20. The Krishi Vigyan Kendra is situated at $26.47^{\circ} \mathrm{N}$ latitude, $77.98^{\circ} \mathrm{E}$ longitude and $177 \mathrm{~m}$ AMSL. The mean annual minimum and maximum temperature ranges from 2 to $50^{\circ} \mathrm{C}$. The average annual precipitation received is 750 $\mathrm{mm}$.

\section{Colony records}

Data on the following colony parameters of experimental colonies was recorded during investigation at an interval of 15 days. 


\section{Colony strength}

The strength of each 3 selected honey bee colonies was recorded in terms of the number of frames covered with bees with both the faces of bee frames taken into account. Total number of the frames covered with bees was taken as bee strength of the whole experimental colony.

\section{Brood area and Pollen area}

The brood area and pollen area was recorded in terms of capped brood and pollen comb cells with the help of a wire grid frame (brood measuring frame), which dispensed well on the four bars of the frames when placed on it. The brood measuring frame consisted of 120 (15 rows $x 8$ columns) squares each of one square inch $\left(2.54 \mathrm{~cm} \mathrm{x} 2.54 \mathrm{~cm}=6.45 \mathrm{~cm}^{2}\right)$ in area.

For measuring the brood and pollen area, the wire grid frame was placed on the hive frame and number of squares of wire grid, covering the brood and pollen area was counted. This provided the brood and pollen area in inch ${ }^{2}$ which was converted into $\mathrm{cm}^{2}$ after multiplying it to a factor of 6.45 .

\section{Honey/nectar stores}

Honey stores were estimated visually on the assumption that one Langstroth frame sealed with bee wax from both sides of the frame contains approximately $2000 \mathrm{~g}$ of honey.

\section{Diseases}

The incidence of diseases that appears in the colonies of honey bee during the entire period of experimentation was recorded according to their respective symptoms at an interval of 15 days. Three colonies were selected to observe the incidence of brood and adult diseases under stationary conditions.

\section{Incidence of Brood Diseases}

30 brood cells in each 3 selected colonies were examined during the diagnosis of brood diseases. Severity of incidence of European foulbrood and Sac brood disease was studied with regard to the per cent brood incidence by using the following formulae:

Percent brood incidence in the colony $=\frac{\text { Diseased brood area }\left(\mathrm{cm}^{2}\right)}{\text { Total brood area }\left(\mathrm{cm}^{2}\right)} \times 100$

\section{European foulbrood disease}

Observation of EFB disease in honeybee colonies is based on the visual inspection of brood-combs and detection of diseased larvae. M. plutonius is mainly found in larvae with visual disease symptoms. The broods of $A$. mellifera colonies were observed based on these visual disease symptoms as under:

Diseased larvae appeared somewhat displaced within the cells as most of the affected larvae die before their cells are capped,

4-5 days young larvae shows change in colour from pearly white to pale yellow and then brown on drying, the scale formed was rubbery in appearance rather being brittle,

A sour odour can be easily detected from the decayed larvae cell, and

Scattered pattern of sealed and unsealed brood cells was observed at the serious stage of infection.

\section{Sac brood disease}

The colonies of $A$. mellifera $\mathrm{L}$. were field diagnosed as Sac Brood Virus infected based on their visual disease symptom, as under:

Newly emerged larva fails to pupate even after four days and at later stage, pupa found 
dead or underdeveloped,

Sealed brood cells with indented holes in their cappings,

Change in colour of larvae from healthy pearly white to yellowish and finally dark brown, and

When infected larva is removed from the cell, it gives the appearance of a small, watery sac without any unpleasant or foul smell.

\section{Statistical analysis}

The collected data were cleared \& stored into Microsoft Excel spread sheets after the completion of data collection work from the study areas for further analysis. Summarized data was presented in the form of tables.

All the research data pertaining to the seasonal incidence of enemies in colonies were transformed using the square root transformation as per the method described by Gomez and Gomez (1986). The data were subjected to statistical analysis by adopting appropriate method of analysis of variance as described by Fisher (1958). Wherever, variance ratio (calculated ' $F$ ' values) was found significant, critical difference (C.D.) values were computed by following formula for making comparison between the treatments.

C.D. $=\sqrt{\frac{\text { error variance }}{n}} \times \sqrt{2} \times \mathrm{t}$

where, $\mathrm{n}=$ The number of observations averaged

Error variance $=$ mean sum of squares due to error and ' $\mathrm{t}$ ' is the value from t-table at $5 \%$ level of significance and at error d.f.

The incidence of diseases was correlated with the weather (temperature, relative humidity, and rainfall) and colony (brood area and colony strength) parameters. The data on Ambient Temperature, Relative humidity and
Rainfall were collected from the RVSKVVZonal Agriculture Research Station, Morena during the Period of experimentation.

\section{Results and Discussion}

The results of present studies were given in Table 1, 2 and 3.

\section{Colony records}

The observations on the colony records in $A$. mellifera colonies under stationary conditions have been recorded at fortnightly interval during July 2019 to February 2020. Three experimental colonies of equal strength of $A$. mellifera in the stationary conditions were kept at Krishi Vigyan Kendra, Morena during the study period.

The data on colony records of A. mellifera during July, 2019 to February 2020 (Table 1) revealed that the average colony strength was 4.1bee frames/ colony in first fortnight of July 2019. Bee colonies gets strength with the bloom of kharif crops in the second fortnight of July (4.3 bee frames/ colony) upto second fortnight of August (5.8 bee frames/colony). The minimum average colony strength was 3.3 to 4.9 bee frames/ colony during second fortnight of September to second fortnight of November when the floral availability was less. With the onset of autumn season, when build up flora was in bloom, experimental colonies gained strength during second fortnight of November (3.8 bee frames/ colony) and gain at its peak in second fortnight of January (8.3 bee frames/ colony). Thereafter, colonies reduced in their average strength to 7.5 and 6.1 bee frames/ colony during first and second fortnight of February 2020, respectively.

The observations on colony records of $A$. mellifera revealed that the average brood area was significantly high $4013.67 \mathrm{~cm}^{2} /$ colony 
during first fortnight of January 2020 followed by average brood area3863.87 $\mathrm{cm}^{2} /$ colony in the second fortnight of December 2019, $3259.29 \mathrm{~cm}^{2} /$ colony in the first fortnight of December 2019 and 3209.33 $\mathrm{cm}^{2} /$ colony in the second fortnight of January 2020. The data further revealed that the average brood area was significantly low i.e.1160.34 $\mathrm{cm}^{2} /$ colony during second fortnight of October 2019 followed by average brood area of $1350.59 \mathrm{~cm}^{2} /$ colony in first fortnight of October 2019, 1523.21 $\mathrm{cm}^{2} /$ colony in first fortnight of July 2019, $1618.71 \mathrm{~cm}^{2} /$ colony in second fortnight of September 2019 and $1668.57 \mathrm{~cm}^{2} /$ colony in first fortnight of November 2019. The average brood area in experimental colonies varied from $1771.30 \mathrm{~cm}^{2} /$ colony (second fortnight of July 2019) to $2470.51 \mathrm{~cm}^{2} /$ colony(second fortnight of November 2019) during rest of the period under observations.

The observations recorded at on average pollen area revealed that the maximum pollen area $1720.71 \mathrm{~cm}^{2} /$ colony was recorded in the first fortnight of February 2020 which was statistically same with pollen area1680.23 $\mathrm{cm}^{2} /$ colony in the second fortnight of January 2020 .

The minimum average pollen area was observed $370.48 \mathrm{~cm}^{2} /$ colony and $345 \mathrm{~cm}^{2} /$ colony in second fortnight of October 2019 and first fortnight of November 2019, respectively. The average pollen area in bee colonies during rest of the period under observations varied from $420.63 \mathrm{~cm}^{2} /$ colony (second fortnight of November 2019) to $1600.23 \mathrm{~cm}^{2} /$ colony(first fortnight of January 2020).

Intone of data in Table 1 showed that average honey store in A. mellifera colonies was observed to be maximum $1660.50 \mathrm{~g} /$ colony in second fortnight of January 2020, followed by $1550.50 \mathrm{~g} /$ colony in the first fortnight of January $2020,1480.50 \mathrm{~g} /$ colony in the first fortnight of February 2020, $1360.00 \mathrm{~g} /$ colony in the second fortnight of December 2019 and $1310.00 \mathrm{~g} /$ colony in the second fortnight of February 2020, values being statistically different from each other. The lowest average honey stores were found $250 \mathrm{~g} /$ colony and $240.50 \mathrm{~g} /$ colony in the second and first fortnight of November 2019, respectively and bees were fed artificially with sugar syrup during these months and other dearth months of the study period on regular basis.

The present findings on colony records at Morena are in line with the earlier observations. In India, winter is the major honey flow season from mustard crop followed by few minor seasons up to early summer (December to May) followed by a long dearth from summer through rainy season till November (Chaudhary, 2003ab; Chaudhary, 2005; Kumar, 2013).Winter and spring season found to be most excellent time for brood production due to presence of optimum weather conditions and bee flora compared to rainy or autumn season. Development of brood area was found to be negatively correlated with temperatures and relative humidity during both the years (Varshneya et al., 2007).

\section{European foul brood disease}

The observations were recorded on the seasonal incidence of European foulbrood disease under stationary conditions at fortnightly intervals during July 2019 to February 2020 in the colonies of A. mellifera. The characteristic symptoms of European foulbrood disease were recorded as, coiled larvae position and spotty brood pattern (Bailey, 1961; Abrol and Ball, 2006; Foresgren, 2010). 
Table.1 Colony records of A. mellifera under stationary conditions during July 2019 to February 2020

\begin{tabular}{|c|c|c|c|c|c|}
\hline \multirow[t]{2}{*}{ Months } & \multirow[t]{2}{*}{ Fortnight } & \multicolumn{4}{|c|}{ Colony Parameters } \\
\hline & & $\begin{array}{c}\text { Colony } \\
\text { Strength (bee } \\
\text { frames) }\end{array}$ & $\begin{array}{c}\text { Brood Area } \\
\left(\mathrm{cm}^{2}\right)\end{array}$ & $\begin{array}{l}\text { Pollen Area } \\
\left(\mathrm{cm}^{2}\right)\end{array}$ & $\begin{array}{c}\text { Honey } \\
\text { Store (g) }\end{array}$ \\
\hline \multirow[t]{2}{*}{ July, 2019} & 1 & 4.10 & $\begin{array}{l}1523.21 \\
(39.03)^{*}\end{array}$ & $\begin{array}{l}657.00 \\
(25.64)\end{array}$ & $\begin{array}{l}436.50 \\
(20.9)\end{array}$ \\
\hline & 2 & 4.30 & $\begin{array}{l}1771.30 \\
(42.09)\end{array}$ & $\begin{array}{l}746.63 \\
(27.33)\end{array}$ & $\begin{array}{l}492.00 \\
(22.19)\end{array}$ \\
\hline \multirow[t]{2}{*}{ August } & 1 & 5.00 & $\begin{array}{l}1934.11 \\
(43.98)\end{array}$ & $\begin{array}{l}993.19 \\
(31.52)\end{array}$ & $\begin{array}{l}580.00 \\
(24.09)\end{array}$ \\
\hline & 2 & 5.80 & $\begin{array}{c}1880.49 \\
(43.37)\end{array}$ & $\begin{array}{l}1210.90 \\
(34.81)\end{array}$ & $\begin{array}{l}720.50 \\
(26.85)\end{array}$ \\
\hline \multirow[t]{2}{*}{ September } & 1 & 5.30 & $\begin{array}{l}1819.63 \\
(42.66)\end{array}$ & $\begin{array}{l}975.00 \\
(31.23)\end{array}$ & $\begin{array}{l}810.50 \\
(28.48)\end{array}$ \\
\hline & 2 & 4.90 & $\begin{array}{l}1618.71 \\
(40.24)\end{array}$ & $\begin{array}{l}725.11 \\
(26.94)\end{array}$ & $\begin{array}{l}650.50 \\
(25.51)\end{array}$ \\
\hline \multirow[t]{2}{*}{ October } & 1 & 4.30 & $\begin{array}{c}1350.59 \\
(36.76)\end{array}$ & $\begin{array}{l}510.23 \\
(22.60)\end{array}$ & $\begin{array}{l}430.00 \\
(20.75)\end{array}$ \\
\hline & 2 & 3.40 & $\begin{array}{c}1160.34 \\
(34.07)\end{array}$ & $\begin{array}{l}370.48 \\
(19.26)\end{array}$ & $\begin{array}{l}290.50 \\
(17.06)\end{array}$ \\
\hline \multirow[t]{2}{*}{ November } & 1 & 3.30 & $\begin{array}{l}1668.57 \\
(40.85)\end{array}$ & $\begin{array}{l}345.00 \\
(18.59)\end{array}$ & $\begin{array}{l}240.50 \\
(15.52)\end{array}$ \\
\hline & 2 & 3.80 & $\begin{array}{c}2470.51 \\
(49.71)\end{array}$ & $\begin{array}{l}420.63 \\
(20.52)\end{array}$ & $\begin{array}{l}250.00 \\
(15.83)\end{array}$ \\
\hline \multirow[t]{2}{*}{ December } & 1 & 5.10 & $\begin{array}{c}3259.29 \\
(57.09)\end{array}$ & $\begin{array}{l}730.11 \\
(27.03)\end{array}$ & $\begin{array}{l}920.50 \\
(30.35)\end{array}$ \\
\hline & 2 & 7.20 & $\begin{array}{c}3863.87 \\
(62.16)\end{array}$ & $\begin{array}{c}1210.19 \\
(34.79)\end{array}$ & $\begin{array}{c}1360.00 \\
(36.88)\end{array}$ \\
\hline \multirow[t]{2}{*}{ January, 2020} & 1 & 8.10 & $\begin{array}{l}4013.67 \\
(63.36)\end{array}$ & $\begin{array}{c}1600.33 \\
(40.01)\end{array}$ & $\begin{array}{l}1550.50 \\
(39.38)\end{array}$ \\
\hline & 2 & 8.30 & $\begin{array}{c}3209.33 \\
(56.66)\end{array}$ & $\begin{array}{l}1680.23 \\
(41.00)\end{array}$ & $\begin{array}{l}1660.50 \\
(40.76)\end{array}$ \\
\hline \multirow[t]{2}{*}{ February } & 1 & 7.50 & $\begin{array}{c}2417.17 \\
(49.17)\end{array}$ & $\begin{array}{c}1720.71 \\
(41.49)\end{array}$ & $\begin{array}{c}1480.50 \\
(38.48)\end{array}$ \\
\hline & 2 & 6.10 & $\begin{array}{l}1988.88 \\
(44.60)\end{array}$ & $\begin{array}{c}1220.30 \\
(34.94)\end{array}$ & $\begin{array}{c}1310.00 \\
(36.20)\end{array}$ \\
\hline C.D. 0.05 & & 0.12 & 0.95 & 0.62 & 0.79 \\
\hline
\end{tabular}

*Figures in parentheses are square root $(\mathrm{x}+1)$ transformed values 
Table.2 Incidence of European foulbrood disease in A. mellifera colonies and its correlation with colony and weather parameters during July, 2019 to February, 2020

\begin{tabular}{|c|c|c|c|c|c|c|c|}
\hline \multirow[t]{2}{*}{ Months } & \multirow[t]{2}{*}{ Fortnight } & \multirow{2}{*}{$\begin{array}{c}\text { EFB } \\
\text { incidence } \\
(\%)\end{array}$} & \multicolumn{2}{|c|}{ Colony Parameters } & \multicolumn{3}{|c|}{ Weather Parameters } \\
\hline & & & $\begin{array}{c}\text { Colony } \\
\text { Strength } \\
\text { (bee frames) }\end{array}$ & $\begin{array}{l}\text { Brood } \\
\text { Area } \\
\left(\mathrm{cm}^{2}\right)\end{array}$ & $\begin{array}{c}\text { Average } \\
\text { Temperature } \\
\left({ }^{\circ} \mathbf{C}\right)\end{array}$ & $\begin{array}{c}\text { Total } \\
\text { Rainfall } \\
\text { (mm) }\end{array}$ & $\begin{array}{c}\text { Average } \\
\text { Relative } \\
\text { Humidity } \\
(\%)\end{array}$ \\
\hline \multirow[t]{2}{*}{ July, 2019} & 1 & $\begin{array}{c}5.00 \\
(2.35)^{*}\end{array}$ & 4.20 & $\begin{array}{l}1590.59 \\
(39.89)\end{array}$ & 31.95 & 127.80 & 62.57 \\
\hline & 2 & $\begin{array}{c}4.00 \\
(2.12)\end{array}$ & 4.50 & $\begin{array}{l}1849.51 \\
(43.01)\end{array}$ & 31.86 & 81.00 & 64.19 \\
\hline \multirow[t]{2}{*}{ August } & 1 & $\begin{array}{c}0.00 \\
(0.71)\end{array}$ & 5.20 & $\begin{array}{c}2042.29 \\
(45.2)\end{array}$ & 28.82 & 106.20 & 73.80 \\
\hline & 2 & $\begin{array}{c}0.00 \\
(0.71)\end{array}$ & 5.90 & $\begin{array}{l}1829.87 \\
(42.78)\end{array}$ & 28.55 & 85.50 & 70.75 \\
\hline \multirow[t]{2}{*}{ September } & 1 & $\begin{array}{c}0.00 \\
(0.71)\end{array}$ & 5.50 & $\begin{array}{l}1770.67 \\
(42.09)\end{array}$ & 29.83 & 60.20 & 75.33 \\
\hline & 2 & $\begin{array}{c}6.00 \\
(2.55)\end{array}$ & 5.00 & $\begin{array}{c}1630.33 \\
(40.38)\end{array}$ & 26.83 & 104.30 & 78.57 \\
\hline \multirow[t]{2}{*}{ October } & 1 & $\begin{array}{l}16.00 \\
(4.06)\end{array}$ & 4.30 & $\begin{array}{l}1419.17 \\
(37.68)\end{array}$ & 28.05 & 30.50 & 58.60 \\
\hline & 2 & $\begin{array}{l}14.00 \\
(3.81)\end{array}$ & 3.60 & $\begin{array}{l}1190.88 \\
(34.52)\end{array}$ & 24.92 & 0.00 & 52.22 \\
\hline \multirow[t]{2}{*}{ November } & 1 & $\begin{array}{c}9.00 \\
(3.08)\end{array}$ & 3.30 & $\begin{array}{l}1610.21 \\
(40.13)\end{array}$ & 24.25 & 0.00 & 49.97 \\
\hline & 2 & $\begin{array}{c}0.00 \\
(0.71)\end{array}$ & 3.70 & $\begin{array}{c}2361.30 \\
(48.6)\end{array}$ & 20.65 & 4.00 & 56.17 \\
\hline \multirow[t]{2}{*}{ December } & 1 & $\begin{array}{c}0.00 \\
(0.71)\end{array}$ & 4.90 & $\begin{array}{l}3290.11 \\
(57.36)\end{array}$ & 17.30 & 22.00 & 63.80 \\
\hline & 2 & $\begin{array}{c}0.00 \\
(0.71)\end{array}$ & 6.80 & $\begin{array}{c}3920.49 \\
(62.62)\end{array}$ & 11.83 & 0.00 & 72.63 \\
\hline \multirow[t]{2}{*}{$\begin{array}{l}\text { January, } \\
2020\end{array}$} & 1 & $\begin{array}{c}0.00 \\
(0.71)\end{array}$ & 8.00 & $\begin{array}{c}4123.63 \\
(64.22)\end{array}$ & 14.33 & 3.90 & 63.10 \\
\hline & 2 & $\begin{array}{c}0.00 \\
(0.71)\end{array}$ & 8.40 & $\begin{array}{c}3409.71 \\
(58.4)\end{array}$ & 14.94 & 30.00 & 65.84 \\
\hline \multirow[t]{2}{*}{ February } & 1 & $\begin{array}{c}0.00 \\
(0.71)\end{array}$ & 7.30 & $\begin{array}{c}2513.59 \\
(50.14)\end{array}$ & 16.27 & 0.00 & 53.07 \\
\hline & 2 & $\begin{array}{l}10.00 \\
(3.24)\end{array}$ & 6.20 & $\begin{array}{l}1990.34 \\
(44.62)\end{array}$ & 20.82 & 0.00 & 51.79 \\
\hline C.D. 0.05 & & 0.13 & 0.06 & 0.62 & & & \\
\hline
\end{tabular}

* Figures in parentheses are square root $(x+1)$ transformed values 
Pearson correlation

\begin{tabular}{|c|c|c|}
\hline & EFB & Regression \\
\hline Colony Strength & $-0.522^{*}$ & -1.835 \\
\hline Brood Area & $-0.627^{*}$ & -0.004 \\
\hline Temperature & $0.341^{\mathrm{NS}}$ & - \\
\hline Rainfall & $-0.144^{\mathrm{NS}}$ & - \\
\hline Relative Humidity & $-0.494^{\mathrm{NS}}$ & - \\
\hline
\end{tabular}

* Significance at 5\% level of significance, ${ }^{\mathrm{NS}}$ Non-significant

Table.3 Incidence of Sacbrood disease in A. mellifera colonies and its correlation with colony and weather parameters during July, 2019 to February, 2020

\begin{tabular}{|c|c|c|c|c|c|c|c|}
\hline \multirow[t]{2}{*}{ Months } & \multirow[t]{2}{*}{ Fortnight } & \multirow{2}{*}{$\begin{array}{c}\text { Sacbrood } \\
\text { incidence } \\
(\%)\end{array}$} & \multicolumn{2}{|c|}{ Colony Parameters } & \multicolumn{3}{|c|}{ Weather Parameter } \\
\hline & & & $\begin{array}{c}\text { Colony } \\
\text { Strength } \\
\text { (bee frames) }\end{array}$ & $\begin{array}{l}\text { Brood } \\
\text { Area } \\
\left(\mathrm{cm}^{2}\right)\end{array}$ & $\begin{array}{c}\text { Average } \\
\text { Temperature } \\
\left({ }^{\circ} \mathbf{C}\right)\end{array}$ & $\begin{array}{c}\text { Total } \\
\text { Rainfall } \\
(\mathbf{m m})\end{array}$ & $\begin{array}{c}\text { Average } \\
\text { Relative } \\
\text { Humidity }(\%)\end{array}$ \\
\hline \multirow[t]{2}{*}{ July, 2019} & 1 & $\begin{array}{c}5.00 \\
(2.35)^{*}\end{array}$ & 4.20 & $\begin{array}{c}1590.59 \\
(39.89)\end{array}$ & 31.95 & 127.80 & 62.57 \\
\hline & 2 & $\begin{array}{c}2.00 \\
(1.58)\end{array}$ & 4.50 & $\begin{array}{l}1849.51 \\
(43.01)\end{array}$ & 31.86 & 81.00 & 64.19 \\
\hline \multirow[t]{2}{*}{ August } & 1 & $\begin{array}{c}0.00 \\
(0.71)\end{array}$ & 5.20 & $\begin{array}{c}2042.29 \\
(45.2)\end{array}$ & 28.82 & 106.20 & 73.80 \\
\hline & 2 & $\begin{array}{c}0.00 \\
(0.71)\end{array}$ & 5.90 & $\begin{array}{l}1829.87 \\
(42.78)\end{array}$ & 28.55 & 85.50 & 70.75 \\
\hline \multirow[t]{2}{*}{ September } & 1 & $\begin{array}{c}0.00 \\
(0.71)\end{array}$ & 5.50 & $\begin{array}{l}1770.67 \\
(42.09)\end{array}$ & 29.83 & 60.20 & 75.33 \\
\hline & 2 & $\begin{array}{c}0.00 \\
(0.71)\end{array}$ & 5.00 & $\begin{array}{l}1630.33 \\
(40.38)\end{array}$ & 26.83 & 104.30 & 78.57 \\
\hline \multirow[t]{2}{*}{ October } & 1 & $\begin{array}{c}0.00 \\
(0.71)\end{array}$ & 4.30 & $\begin{array}{l}1419.17 \\
(37.68)\end{array}$ & 28.05 & 30.50 & 58.60 \\
\hline & 2 & $\begin{array}{c}0.00 \\
(0.71)\end{array}$ & 3.60 & $\begin{array}{c}1190.88 \\
(34.52)\end{array}$ & 24.92 & 0.00 & 52.22 \\
\hline \multirow[t]{2}{*}{ November } & 1 & $\begin{array}{c}0.00 \\
(0.71)\end{array}$ & 3.30 & $\begin{array}{l}1610.21 \\
(40.13)\end{array}$ & 24.25 & 0.00 & 49.97 \\
\hline & 2 & $\begin{array}{c}0.00 \\
(0.71)\end{array}$ & 3.70 & $\begin{array}{c}2361.30 \\
(48.6)\end{array}$ & 20.65 & 4.00 & 56.17 \\
\hline \multirow[t]{2}{*}{ December } & 1 & $\begin{array}{c}0.00 \\
(0.71)\end{array}$ & 4.90 & $\begin{array}{c}3290.11 \\
(57.36)\end{array}$ & 17.30 & 22.00 & 63.80 \\
\hline & 2 & $\begin{array}{c}0.00 \\
(0.71)\end{array}$ & 6.80 & $\begin{array}{c}3920.49 \\
(62.62)\end{array}$ & 11.83 & 0.00 & 72.63 \\
\hline \multirow[t]{2}{*}{ January, 2020} & 1 & $\begin{array}{c}0.00 \\
(0.71)\end{array}$ & 8.00 & $\begin{array}{c}4123.63 \\
(64.22)\end{array}$ & 14.33 & 3.90 & 63.10 \\
\hline & 2 & $\begin{array}{c}0.00 \\
(0.71)\end{array}$ & 8.40 & $\begin{array}{c}3409.71 \\
(58.4)\end{array}$ & 14.94 & 30.00 & 65.84 \\
\hline \multirow[t]{2}{*}{ February } & 1 & $\begin{array}{c}5.00 \\
(2.35)\end{array}$ & 7.30 & $\begin{array}{c}2513.59 \\
(50.14)\end{array}$ & 16.27 & 0.00 & 53.07 \\
\hline & 2 & $\begin{array}{c}7.30 \\
(2.79)\end{array}$ & 6.20 & $\begin{array}{c}1990.34 \\
(44.62)\end{array}$ & 20.82 & 0.00 & 51.79 \\
\hline C.D. 0.05 & & 0.09 & 0.06 & 0.62 & & & \\
\hline
\end{tabular}

* Figures in parentheses are square root $(x+1)$ transformed values 
Pearson correlation

\begin{tabular}{|c|c|c|}
\hline & Sac brood & Regression \\
\hline Colony Strength & $0.127^{\mathrm{NS}}$ & - \\
\hline Brood Area & $-0.560^{*}$ & 0.552 \\
\hline Temperature & $0.038^{\mathrm{NS}}$ & - \\
\hline Rainfall & $0.006^{\mathrm{NS}}$ & - \\
\hline Relative Humidity & $-0.422^{\mathrm{NS}}$ & - \\
\hline
\end{tabular}

NS (Non-significant.

The data on incidence of European foulbrood disease in A. mellifera colonies (Table 2) revealed that the average colony incidence of European foulbrood was observed at 5\% and $4 \%$ in the first and second fortnight of July 2019, respectively during the beginning of the study period. The incidence of European foulbrood disease was found maximum at $16 \%$ during study period in the first fortnight of October 2019. The high incidence of European foulbrood during second fortnight of September 2019 to second fortnight of October 2019 showed significant reduction in colony strength and brood area. The incidence of European foulbrood reduced to 9\% significantly in the first fortnight of November 2019. The disease was found to disappear from experimental colonies, during first fortnight of August 2019 to first fortnight of September 2019 and from second fortnight of November 2019 to first fortnight of February 2020 when bee colonies were observed healthy. During 2020, European foulbrood disease reappeared in second fortnight of February 2020 with 10\% brood infestation.

The data on correlation of incidence of European foulbrood with colony and weather parameters in A. mellifera colonies under stationary conditions showed that the incidence of European foulbrood was significantly negative with colony strength $(\mathrm{r}=$ $-0.522)$ and brood area $(\mathrm{r}=-0.627)$. The incidence of European foulbrood was found positively correlated with temperature $(r=$
0.341 ), and negatively correlated with rainfall $(\mathrm{r}=-0.144)$ and relative humidity $(\mathrm{r}=-0.494)$, though non-significant.

Rao (2009) have also recorded maximum incidence of European foulbrood in September (18.52\%) in A. mellifera colonies at Nauni. He also observed that A. mellifera colonies during winter months were free from European foulbrood infestation. Similar extents of damage have been also reported in A. mellifera colonies (Moffett, 1952; Giavarini, 1956; Buza and Kovacs, 1969) in other countries by different workers in different parts of world. These workers have also reported positive correlation of incidence of European foulbrood disease in different months of year in relation to bee strength, temperature, rainfall and relative humidity. The reason of absence of European foulbrood disease during winter months from second fortnight of November, 2019 to first fortnight of February, 2020 could be attributed to the fact that in these months bee flora is available in abundant that results in strong build-up of bee colonies and develops high potential to detect and removed by bees. Bailey (1960) and Simpson (1960) have also reported direct influence of supply of glandular food by nurse bees on appearance and disappearance of European foulbrood in A.mellifera. The incidence of disease was negatively correlated with colony strength. This again could be due the absence of essential food required during the dearth period. 


\section{Sac brood disease}

Sac brood disease incidence was recorded in A. mellifera colonies in stationary conditions at fortnightly intervals during July 2019 to February 2020 (Table 3) revealed that the brood population in bee colonies experiences $5 \%$ and $2 \%$ brood infestation in the first and second fortnight of July 2019, respectively. Brood was also found infested in the first and second fortnight of February 2020 with 5\% and $7.30 \%$ brood infestation, respectively.

The bee colonies were found to be free from this disease during the rest of months from first fortnight of August 2019 to second fortnight of January 2020. Appearance of sac brood virus showed typical symptoms in brood cells, sac like structure of brood filled with fluid and sunken perforated capping of brood cells and scattered brood pattern (Bailey 1981; Berenyi et al., 2006).

The data on the correlation of incidence of Sac brood with the colony and weather parameters in A. mellifera colonies under stationary conditions showed that the incidence of Sac brood disease was found significantly negative correlated with brood area $(\mathrm{r}=-0.560)$ and relative humidity being non-significant. Also the incidence of Sac brood disease shows positively correlated with colony strength, average temperature and rainfall, though non-significant. This could be due to altered weather conditions during the study period.

During the time of present investigation, sac brood disease was discovered missing all through the investigation time frame with the exception of in the long stretch of July 2019 and February 2020 having a little rates of brood infestation.

The purpose behind disappearance of the disease all through the examination time frame, i.e., from August 2019 to January 2020 , could be because of less susceptibility of Apis mellifera when contrasted with other honeybee species.

These observations are supported by the finding of Rana and Rana (2015), who had reported the incidence of sac brood disease during April to May when colony strength and brood area started increasing at faster rate during the study at Nauni, Solan and the incidence of the disease were found to be significantly correlated with colony strength and brood rearing. The occurrence of disease during spring (February-March) to summer have also been reported by different workers (Chandel et al., 1999, Hornitzky and Anderson, 2003; Mohan Rao, 2015).

\section{Acknowledgement}

The authors acknowledge the support from the Department of Entomology Gwalior, Associate Director Research ZARS, Morena and Senior Scientist \& Head, Krishi Vigyan Kendra, Morena.

\section{References}

Abrol, D.P. and Ball, B.V. (2006). New record of European foulbrood (EFB): a bacterial disease of honey bee Apis mellifera $\mathrm{L}$. in Jammu, India. J. Res., 5: 256-260.

Bailey, L. (1960). The Epizootiology of European foul brood of the larval honey bee, Apis mellifera L. J. of Ins. Path. 2: 67-83

Bailey, L. (1961). European foulbrood. Am. Bee J. 101, 89-92.

Bailey, L. (1961). Honey Bee Pathology. Academic Press, London. 129 p.

Bailey, L. (1981). Honey bee pathology. Academic Press Inc. 124 p.

Berenyi, O., Bakonyi, T., Derakhshifar, I., Koglberger, H. and Nowotny, N. (2006). Occurrence of six honeybee viruses in diseased Austrian apiaries. Appl. and Environ. Microbiol. 72: 2414- 2420

Buza, L. and Kovacs, F. (1969). Occurrence of 
European foul brood and its control. Hungary Mcheszet 17: 123-124

Chandel, Y.S., Kumar, A. and Ball, B.V. (1999). Sacbrood disease in Italian honey bee, Apis mellifera L., in Himachal Pradesh, India. Pest Management and Econ. Zool. 7: 181182

Chaudhary, O.P. (2003a). Evaluation of honey bee flora of the north eastern region of Haryana. J. Palynology. 39:127-141.

Chaudhary, O.P. (2003b). Performance of Apis mellifera Linn. in the north eastern Haryana. Indian Bee J. 65 (1\&2):25-35

Chaudhary, O.P. (2005. Incidence and intensity of Varroa destructor on Apis mellifera L. honeybees in Haryana migratory region. Indian Bee J. 67 (3\&4): 121- 127.

Diwan, V.V., Kshirsagar, K.K., Raman, R.A.V., Raghunath, D., Bhambure, C.S. and Godbole, S.H. (1971). Occurrence of new bacterial disease of Indian honey bee (Apis indica F.). Current Science 40: 196-197

Fisher. (1958). The genetical theory of natural selection. $2^{\text {nd }}$ edition Dover publications, New York.

Forsgren, E. (2010). European foulbrood in honey bees. J. of Invertebrate Path. 103: 55-59

Genersch, E. (2010). Honey bee pathology: current threats to honey bees and beekeeping. J. App. Microbiol. Biotech. 87: 87-97

Giavarini, I. (1956). Bee diseases in Italian. Annals Springer Agriculture 10: 99-115

Gomez, K.A. and Gomez, A.A. (1986). Statistical procedures for agricultural research. 2nd edition John Wiley and Sons, New York. pp 99-107

Hornitzky, A.Z. and Anderson, D.L. (2003). Honeybee diseases. Australia and New Zealand Standard Diagnostic Procedures
38: $1-13$

Johannesmeier, M.F. and Mostert, A.J.N. (2001). Crop pollination. In: Beekeeping in South Africa. Pretoria Agricultural Research Council, South Africa. pp 235-250

Kumar, R., Rajput, G.S., Ahmad, S. (2013). Assessment of dearth periods for honey bees (Apis mellifera) in Gwalior (MP), India. Munis Entomology \& Zoology. 8(2):745-8.

Moffett, J.O. (1952). Antibiotics control of European foulbrood. Farm and Home Research 3: 3- 11

Mohan Rao, K., Katna, S., Rana, B.S. and Rana, R., (2015). Thai sacbrood and sacbrood viruses versus European foulbrood of hive bees in India-a review. $J$. of Apicultural Research, 54(3), pp.192-199.

Rana, B.S. and Rana, R. (2015). Detection of sacbrood virus and the incidence of sacbrood disease in Apis mellifera colonies in the North-Western Himalayas. $J$. of Apicultural research, 47(1), pp. 58-62

Rao, M.K. (2009). Molecular characterization of Melissococcus pluton of hive honey bees and its control with antibiotics. Ph.D. Thesis. Dr Y S Parmar University of Horticulture and Forestry, Nauni, Solan. $78 \mathrm{p}$

Simpson, J. (1960). The functions of salivary glands of Apis mellifera. J. Insect Physiology. 4: 107

Varshneya I., Pandey K.A. and Rathore, R.R.S. (2007). Effect of weather parameters on brood development on European Honey Bee Apis mellifera L. in different seasons. Journal of Entomology Research 31(4): 347-354.

\section{How to cite this article:}

Naveen and Ashok Singh Yadav. 2021. Seasonal Incidence of European Foul Brood and Sac Brood Disease in Apis mellifera L. and their Correlation with Colony and Weather Parameters. Int.J.Curr.Microbiol.App.Sci. 10(01): 13-24. doi: https://doi.org/10.20546/ijcmas.2021.1001.003 